\title{
Algoritma Needleman-Wunsch dalam Menentukan Tingkat Kemiripan Urutan DNA Rusa Timor (Cervus timorensis) dan Rusa Merah (Cervus elaphus)
}

\author{
Hibban Kholiq, ${ }^{a, *}$,Mamika Ujianita Romdhini ${ }^{b}$, Marliadi Susanto ${ }^{c}$ \\ a, * Program Studi Matematika, Universitas Mataram, Jl Majapahit No. 62, Mataram, Indonesia, 83125. \\ Email: hibbankholiq77@gmail.co.id \\ b Program Studi Matematika, Universitas Mataram, J1 Majapahit No. 62, Mataram, Indonesia, 83125. \\ Email: mamika_ur@yahoo.co.id \\ c Program Studi Matematika, Universitas Mataram, Jl Majapahit No. 62, Mataram, Indonesia, 83125. \\ Email: marliadisusanto@yahoo.co.id
}

\section{A B S T R A C T}

Sequence alignment is a basic method in sequence analysis. This method is used to determine the similaritiy level of DNA sequences. The Needleman-Wunsch algorithm is an algorithm that can be used to solve the problem of sequence alignment. This research shows that the relation $\mathrm{T}(\mathrm{i}, \mathrm{j})$ used in the Needleman-Wunsch algorithm is a function where $\mathrm{T}:\left(\mathbb{N}_{0} \times \mathbb{N}_{0}\right) \rightarrow \mathbb{Z}$. The function $\mathrm{T}(\mathrm{i}, \mathrm{j})$ is a recursive function. Moreover, DNA sequence data used are DNA sequences from the Timor Deer, which are the identities of the provinces of West Nusa Tenggara and Red Deer, which are typical deer from the European continent as a comparison. The DNA sequence data was obtained from BLAST (Basic Local Alignment Search Tool). Based on the alignment, the most optimal alignment is obtained by forming 666 base pairs sequences with 322 matches, 230 missmatches and 114 gaps, meaning that the two DNA sequences have a $48 \%$ similarity $(322 / 666)$.

Keywords: DNA, Sequence Alignment, Needleman-Wunsch Algorithm, Dynamic Programming, Recursive Function, Similarities

\section{A B S T R A K}

Penjajaran urutan(Sequence alignment) merupakan metode dasar dalam analisis urutan. Metode ini digunakan untuk mengetahui tingkat kemiripan urutan DNA. Algoritma Needleman-Wunsch merupakan salah satu algoritma yang dapat digunakan untuk menyelesaikan permasalahan penjajaran urutan. Penelitian ini menunjukkan bahwa relasi $T(i$ ,j) yang digunakan dalam algoritma Needleman-Wunsch merupakan fungsi dimana $T:\left(\mathbb{N}_{0} \mathrm{X} \mathbb{N}_{0}\right) \rightarrow \mathbb{Z}$. Fungsi $T(i$,

* Corresponding author.

Alamat e-mail: hibbankholiq77@gmail.co.id 
j) merupakan fungsi rekursif. Selanjutnya, data urutan DNA yang digunakan adalah urutan DNA dari Rusa Timor yang merupakan identitas provinsi Nusa Tenggara Barat dan Rusa Merah yang merupakan Rusa khas dari benua Eropa sebagai pembanding. Data urutan DNA tersebut diperoleh dari BLAST (Basic Local Alignment Search Tool). Berdasarkan hasil penjajaran, diperoleh penjajaran yang paling optimal dengan terbentuk 666 urutan pasangan basa dengan 322 match, 230 missmatch, dan 114 gap, artinya kedua urutan DNA tersebut memilik kemiripan sebesar $48 \%(322 / 666)$.

Kata Kunci: DNA, Penjajaran Urutan, Algoritma Needleman-Wunsch, Program Dinamik, Fungsi Rekursif, Tingkat Kemiripan. Doi: https://doi.org/10.29303/emj.v3i2.65

\section{Pendahuluan}

Asam deoksiribonukleat, lebih dikenal dengan singkatan DNA (deoxyribonucleic acid), adalah sejenis biomolekul yang menyimpan dan menyandi informasi-informasi genetika setiap organisme dan beberapa jenis virus. Informasi-informasi genetika ini berperan penting dalam pertumbuhan, perkembangan, dan fungsi organisme dan virus. DNA merupakan cetak biru individu karena DNA memiliki informasi genetik yang membentuk sel-sel dalam organisme. Molekul DNA berperan sebagai penyimpanan informasi jangka panjang. DNA berbentuk heliks ganda yang disusun dari unit-unit nukleotida yang berulang. Heliks ganda DNA distabilkan oleh ikatan hidrogen diantara empat basa (asam nukleat) yang melekat pada dua heliks secara berpasangan. Empat asam nukleat tersebut adalah Adenin (disingkat A), Sitosin (C), Guanin (G) dan Timin (T) (Wikipedia). DNA akan memberikan keunikan tertentu kepada setiap individu. Artinya tidak akan ada dua individu yang sama persis, karena pasti ada perbedaan pada kombinasi DNA-nya. Kelestaraian dan keunikan yang menjadi hasil karya DNA tersebut berlaku baik pada faktor fisik ataupun karakter individu. Pada sebagian besar organisme, pewarisan DNAtidak dapat berlangsung sempurna, disebabkan adanya faktor pembatas lingkungan, seperti degenerasi gen dan mutasi (Zen, 2006).

Bioinformatika sebagai bidang ilmu yang mencakup penerapan metode-metode matematika, statistika, dan informatika merupakan ilmu yang mempelajari penerapan teknik komputasional untuk mengelola dan menganalisis informasi biologis sebagai pemecahan masalah-masalah biologis (Wikipedia). Salah satu penerapan bioinformatika adalah penjajaran urutan DNA. Penjajaran urutan (sequence alignment) adalah proses penyusunan/pengaturan dua atau lebih urutan sehingga persamaan urutan-urutan tersebut tampak nyata. Hasil dari proses tersebut juga disebut sebagai sequence alignment atau alignment saja .
Penjajaran urutan (Sequence alignment) merupakan metode dasar dalam analisis urutan. Metode ini digunakan untuk mempelajari evolusi urutan-urutan dari leluhur yang sama (common ancestor) (Bu'ulölö dkk., 2010). Dengan kata lain metode ini dapat digunakan untuk mengetahui kemiripan urutan DNA dari dua atau lebih makhluk hidup yang saat ini dikenal sebagai makhluk hidup yang berbeda namun terdapat kemungkinan memiliki leluhur yang sama. Secara umum penjajaran urutan dapat dibedakan menjadi dua jenis berdasarkan urutan yang digunakan yaitu penjajaran urutan lokal dan penjajaran urutan global. Pada penjajaran lokal, urutan yang digunakan hanya berfokus pada potongan dari keseluruhan urutan yang dianggap memilki kemiripan yang signifikan. Sedangkan penjajaran global menggunakan keseluruhan panjang urutan untuk dibandingkan (Kusuma, 2019).

Penelitian ini menggunakan penjajaran urutan global, yaitu melakukan pembandingan terhadap keseluruhan urutan DNA. Algoritma yang populer dalam penyelesaian penjajaran urutan global adalah algoritma Needleman-Wunsch. Algoritma ini telah banyak digunakan dalam penelitian, diantaranya Malendes (2017), Kusuma (2019), Bu'ulölö (2010) dan penelitian-penelitian lainnya. Pada skripsi ini akan ditunjukkan bagaimana prinsip dasar matematis pada algoritma Needleman-Wunsch dalam penyelesaian penjajaran urutan untuk mengetahui kemiripan urutan DNA dari Rusa Timor (Cervus Timorensis) dengan Rusa merah (Cervus elaphus) dari Eropa. Rusa Timor dipilih karena rusa ini merupakan rusa endemik Indonesia dan merupakan spesies bendera (flag species) bagi provinsi Nusa Tenggara Barat (NTB), bahkan telah menjadi lambang bagi provinsi ini (Utomo dan Hasan, 2014). Sedangkan Rusa merah dipilih sebagai pembanding karena terletak di benua yang berbeda yang tentu memiliki karakteristik lingkungan yang berbeda. Hal ini dilakukan selain untuk menelaah proses penyelesaian masalah penjajaran urutan, juga untuk 
mengetahui tingkat kemiripan susunan DNA pada dua jenis rusa tersebut.

\section{Tinjauan Pustaka}

\subsection{Fungsi}

Konsep fungsi merupakan hal yang penting dalam berbagai bahasan matematika. Sebagaimana diperkenalkan oleh Leibnitz (1646-1716), kata fungsi dalam matematika digunakan untuk menyatakan suatu hubungan atau relasi yang khusus antara dua himpunan (Khairunnisa, 2014).

Definisi 2.1.1 (Munir, 2010)

Misalkan $A$ dan $B$ himpunan. Relasi biner $f$ dari $A$ ke $B$ merupakan suatu fungsi jika setiap elemen di dalam $A$ dihubungkan dengan tepat satu elemen di dalam $B$. Fungsi $f$ dari $A$ ke $B$ dapat dituliskan

$$
f: A \rightarrow B
$$

yang artinya $f$ memetakan $A$ ke $B$.

Dalam fungsi, dikenal juga istilah nilai maksimum dan nilai minimum.

Definisi 2.1.2. (Ratnadewi, 2016)

Misalkan $\mathrm{S}$ adalah daerah asal $f$ memuat titik c, dikatakan bahwa

i. $f(c)$ adalah nilai maksimum $f$ pada $\mathrm{S}$ jika $f(c)$ $\geq f(x)$ untuk semua $x$ di S

ii. $f(c)$ adalah nilai minimum $f$ pada $\mathrm{S}$ jika $f(c) \leq$ $f(x)$ untuk semua $x$ di S

iii. $f(c)$ adalah nilai ekstrim $f$ pada $\mathrm{S}$ jika $f(c)$ adalah nilai maksimum atau minimum

\subsection{Program Dinamis}

Program dinamis merupakan salah satu algoritma untuk memecahkan permasalahan kompleks dengan membagi permasalahan menjadi langkah-langkah dan menggabungkan solusi dari hasil tiap langkah yang dibuat. Salah satu sifat dari program dinamis adalah adanya keterhubungan antara sub-masalah hingga masalah yang lebih besar, dimana keterhubungan tersebutlah yang digunakan untuk membangun persamaan sebagai solusi, atau yang disebut sebagai Bellman equation. Langkah-langkah pemecahan masalah dengan program dinamis secara umum yaitu: (Lokawati, 2016)
1. Mendefinisikan sub-masalah

2. Menentukan rekursi dan atau fungsi berkaitan dengan sub-masalah tersebut

3. Menyatukan solusi

Siagian (1987) mengemukakan bahwa prosedur pemecahan persoalan dalam program dinamik dilakukan secara rekursif. Ini berarti bahwa setiap kali mengambil keputusan, harus memperhatikan keadaan yang dihasilkan oleh keputusan sebelumnya. Karena itu, keadaan yang diakibatkan oleh suatu keputusan sebelumnya dan merupakan landasan bagi keputusan berikutnya, sehingga konsep tentang keadaan adalah sangat penting.

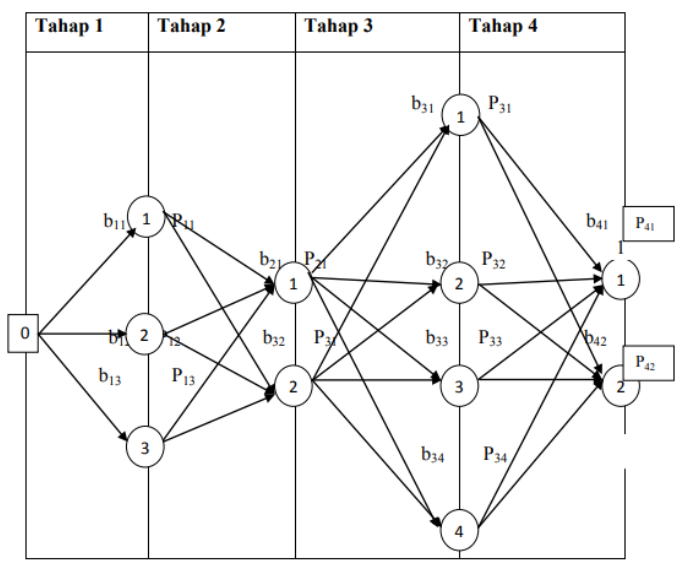

Gambar 2.2. Diagram Jaringan Keputusan

\subsection{Fungsi Rekursif}

Definisi 2.3.1. (Siang, 2004)

Suatu barisan didefinisikan secara rekursif jika kondisi awal (basis) barisan ditentukan, dan sukusuku barisan selanjutnya dinyatakan dalam hubungannya dengan sejumlah suku-suku yang sudah dinyatakan sebelumnya. Persamaan yang menyatakan hubungan antara beberapa suku tersebut dinamakan relasi rekurensi.

Sebagai contoh, barisan bilangan ganjil lebih besar dari 2, yaitu $3,5,7, \ldots$ dapat dinyatakan sebagai berikut:

Untuk semua bilangan bulat $\mathrm{k} \geq 1$,

$$
\begin{aligned}
& \mathrm{a}_{\mathrm{k}}=\mathrm{a}_{\mathrm{k}-1}+2 \text { (relasi rekurensi) dan } \\
& \mathrm{a}_{0}=3 \text { (kondisi awal/basis) }
\end{aligned}
$$

dengan relasi rekurensi dan kondisi awal, suku-suku barisan selanjutnya dapat dihitung sebagai berikut :

$$
\mathrm{a}_{1}=\mathrm{a}_{0}+2=3+2=5
$$




$$
\begin{aligned}
& \mathrm{a}_{2}=\mathrm{a}_{1}+2=5+2=7 \\
& \mathrm{a}_{3}=\mathrm{a}_{2}+2=7+2=9
\end{aligned}
$$

Ada beberapa contoh fungsi rekursif, diantaranya:

$$
\text { 1. } F(x)= \begin{cases}0 & , x=0 \\ 2 F(x-1)+x^{2} & , x \neq 0\end{cases}
$$

2. Fungsi Fibonacci:

$$
f(n)= \begin{cases}0 & , n=0 \\ 1 & , n=1 \\ f(n-1)+f(n-2) & , n>1\end{cases}
$$

\subsection{Matriks}

Definisi 2.4.1. (Munir, 2010)

Matriks adalah susunan elemen-elemen dalam bentuk baris dan kolom.

Sebuah matriks adalah susunan segi empat sikusiku dari bilangan-bilangan atau fungsi. Bilanganbilangan atau fungsi dalam susunan tersebut dinamakan entri / elemen dan diapit oleh dua kurung siku. Matriks A yang berukuran $\mathrm{m}$ baris dan $\mathrm{n}$ kolom dengan $m, n \in \mathbb{Z}$ dapat ditulis sebagai berikut:

$$
A=\left[\begin{array}{cccc}
a_{11} & a_{12} & \cdots & a_{1 n} \\
a_{21} & a_{22} & \cdots & a_{2 n} \\
& \vdots \vdots & \ddots & \vdots \\
a_{m 1} & a_{m 2} & \cdots & a_{m n}
\end{array}\right]
$$

Entri $a_{i j}$ disebut elemen matriks pada baris ke- $i$ dan kolom ke-j. Jika $m=n$, maka matriks tersebut dinamakan juga matriks bujursangkar (square matriks). Penulisan matriks biasa disingkat $A=\left[a_{i j}\right]$.

\subsection{Penjajaran Urutan DNA}

Penjajaran urutan adalah proses penyusunan/pengaturan dua atau lebih urutan sehingga persamaan urutan-urutan tersebut tampak nyata. Sequence alignment pada urutan protein dilakukanuntuk mencari tingkat kesamaan di antara urutan-urutan yang disejajarkan. Dengan mengetahui tingkat kemiripan urutan protein, maka akan lebih mudahuntuk mencari struktur dan fungsi dari proteintersebut.

Berikut adalah contoh alignment protein dari duaurutan pendek protein yang berbeda, "MNENLFAS"dan "MMENGGGLFAS" (tanda ":" menunjukkan kecocokan atau match di antara kedua urutan).

$\begin{array}{lllllllllll}\text { M } & \text { N } & \text { E } & \text { N } & - & - & - & \text { L } & \text { F } & \text { A } & \text { S } \\ : & & : & : & & & & : & : & : & : \\ \text { M } & \text { M } & \text { E } & \text { N } & \text { G } & \text { G } & \text { G } & \text { L } & \text { F } & \text { A } & \text { S }\end{array}$

Ketidak cocokan (mismatch) dalam alignment diasosiasikan dengan proses mutasi, sedangkan kesenjangan (gap, tanda "-") diasosiasikan dengan proses insersi (bertambahnya sekumpulan asam amino yang baru dalam urutan) atau delesi (sejumlah asam amino yang hilang dalam suatu urutan) (Bu’ulölö, dkk., 2010).

\subsection{Algoritma Needleman-Wunsch}

Algoritma Needleman-Wunsch (N-W) ini pertama kali diusulkan oleh Saul B. Needleman dan Christian D. Wunsch pada tahun 1970, Algoritma Needleman Wunsch melakukan sequence alignment global, yaitu melihat total global sequence alignment yang memiliki tingkat kemiripan yang tinggi dari global penjajaran urutan (Satradkk., 2015).

Berikut langkah-langkah dalam Algoritma N-W :

1. Inisialisasi tabel $\mathrm{T}$

Untuk penjajaran 2 urutan, diberikan S1 (urutan pertama) dan S2 (urutan kedua), dengan panjang $m$ dan $n$, dimulai dengan membuat sebuah tabel T dengan $m+1$ kolom dan $n+1$ baris.

Contoh : S1='TGGTG' dan S2='ATCGT', $m=5$ dan $n=5$

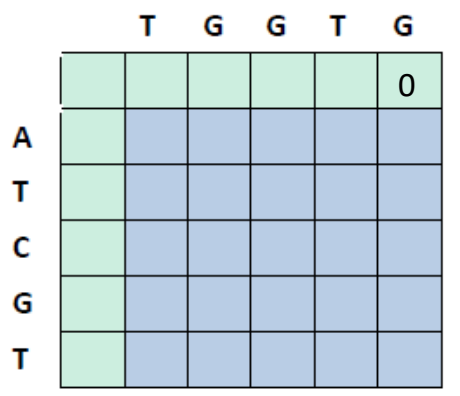

2. Pengisian nilai tabel $\mathrm{T}$

Tabel $\mathrm{T}$ kemudian diisi dengan menggunakan hubungan rekursif

$$
T(i, j)=\max \left\{\begin{array}{l}
T(i-1, j-1)+\operatorname{sim}\left(S_{1}(i), S_{2}(j)\right) \\
T(i-1, j)+\text { gap penalty } \\
T(i, j-1)+\text { gap penalty }
\end{array}\right.
$$


Keterangan :

$T(i, j)=$ fungsi optimum pada

penjajaran urutan DNA

$i=0,1,2, \ldots, \mathrm{m}$ (indeks kolom)

$j=0,1,2, \ldots, \mathrm{n}$ (indeks baris)

$\operatorname{sim}\left(S_{1}(i), S_{2}(j)\right)=\left\{\begin{array}{r}1, \text { match } \\ -1, \text { unmatch }\end{array}\right.$

$d=-2($ gap penalti)

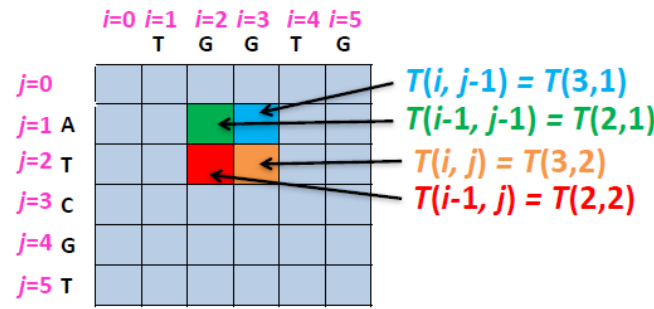

3. Pelacakan kembali (trace back)

Pelacakan kembali (trace back) merupakan tahap terakhir dari algoritma Needleman-Wunsch, pada tahap ini digunakan matriks $\mathrm{T}$ yang sudah diisi untuk mendapatkan penjajaran terbaik di antara dua urutan S1 dan S2.

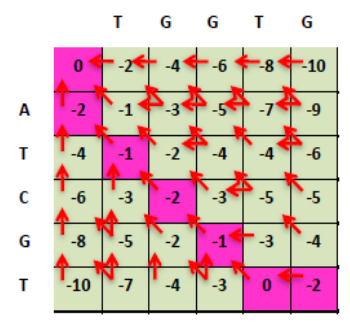

- T G G T G I 11 A T C G T -

dimulai dari pojok kanan bawah dari sel matriks $\mathrm{T}$, kemudian ikuti tanda panah. Tanda panah menunjukkan sel yang digunakan sebelumnya untuk kalkulasi hasil terbaik untuk sel tersebut. Dari sini, ikuti tanda panah ke sel sebelumnya dan lakukan seterusnya hingga diperoleh penjajaran urutan terbaiknya.

\section{Metode Penelitian}

Data yang digunakan adalah data urutan DNA Rusa Timor (Cervus timorensis) dan Rusa Merah (Cervus elaphus) yang diperoleh dari BLAST (Basic Local Alignment Search Tool). BLAST merupakan perkakas bioinformatika yang berkaitan erat dengan penggunaan basis data urutan biologis.

Penelitian ini terdiri atas beberapa tahapan yaitu:
1. Analisis Program Dinamis pada Penjajaran Urutan DNA

2. Penjajaran urutan DNA Rusa Timor dan Rusa Merah

3. Menguji kemiripan urutan DNA Rusa Timor dan Rusa Merah dengan algoritma NeedlemanWunsch

4. Penarikan kesimpulan

\section{Hasil dan Pembahasan}

Program dinamik adalah teknik optimasi untuk permasalahan yang dapat dibagi menjadi beberapa tahap (stage), dimana pada tiap tahap harus diambil suatu keputusan (decision) yang tergantung pada kedudukannya pada tahap ini dan keputusan tersebut akan menentukan keadaan/kedudukan (state) nya pada tahap berikutnya.

\subsection{Analisis Program Dinamik pada PenjajaranUrutan DNA}

Torres (2003) menjelaskan bahwa pada masalah penjajaran urutan dua buah DNA dengan panjang urutan masing-masing $m, n$ dimana $m, n$ adalah bilangan bulat, dapat dihitung banyaknya kombinasi urutan yang mungkin terbentuk dengan menggunakan persamaan berikut:

$$
f(n, m)=\sum_{k=0}^{\operatorname{Min}[m, n]} 2^{k}\left(\begin{array}{l}
m \\
k
\end{array}\right)\left(\begin{array}{l}
n \\
k
\end{array}\right)
$$

semakin besar nilai $\mathrm{m}$ dan $\mathrm{n}$, maka semakin banyak pula kombinasi yang dapat terbentuk. Diketahui bahwa untuk $m=n=100$ diperoleh $f(n, m) \approx 2 \times$ $10^{74}$.

Program dinamik dapat digunakan untuk menentukan urutan terbaik dari pencocokan dua urutan DNA dengan membagi proses perhitungannya kedalam beberapa tahap yang lebih mudah diselesaikan.

Diberikan dua buah urutan DNA, urutan $A=a_{1}$, $a_{2}, a_{3, \ldots}, a_{i}$ dan urutan $B=b_{1}, b_{2}, b_{3, \ldots}, b_{j}$. Masalah penjajaran DNA $A$ dan $B$ dapat dirumuskan menjadi masalah memaksimumkan fungsi $S$ berikut:

$$
S=n_{\text {gap }} \times d+n_{\text {match }} \times m+n_{\text {unmatch }} \times u
$$

Dimana,

$n_{\text {gap }}=$ banyaknya gap

$n_{\text {match }}=$ banyaknya match

$n_{\text {unmatch }}=$ banyaknya unmatch 
$d=$ penalti $g a p=-2$

$m=$ nilai match $=1$

$u=$ penalti unmatch $=-1$

karena nilai unmatch dan nilai gap bernilai negatif sedangkan nilai match bernilai positif, maka nilai $S$ akan maksimum ketika nilai $n_{\text {match }}$ besar.

Selanjutnya untuk menentukan nilai optimal dari penjajaran urutan A dan urutan B (A-B) dengan program dinamik, dapat dibuat beberapa tahapan dengan membuat sub-urutan dari urutan A dan urutan B. Misal $A_{1}=a_{i,} a_{i-1}, a_{i-2, \ldots}, a_{3}, a_{2}, a_{1}$ adalah sub-urutan dari A, dan $B_{1}=b_{j,}, b_{j-1}, b_{j-2, \ldots,} b_{3,}, b_{2}, b_{1}$ adalah suburutan dari B. Kemudian, masalah penjajaran DNA $A$ dan $B$ dapat dipecah menjadi 3 sub-masalah, yaitu: penjajaran $A_{1}-B_{l}, A-B_{l}$, dan $A_{l}-B$. Pada penjajaran $A_{1}-B_{1}$, yang dilihat match dan unmatch dari $a_{l}$ dan $b_{1}$ - Sehingga jika $S_{l}$ adalah nilai optimum dari penjajaran $A_{l}-B_{l}$, maka penjajaran $A-B$ memiliki nilai

$$
S=S_{1}+\text { matau }_{1}+u
$$

Selanjutnya pada penjajaran $A-B_{l}$, karena $a_{l}$ dipasangkan dengan gap, sehingga jika $S_{2}$ adalah nilai optimum dari penjajaran $A$ - $B_{1}$ maka penjajaran $A$ - $B$ memiliki nilai

$$
S=S_{2}+d
$$

Kemudian pada penjajaran $A_{l}-B$, karena $b_{l}$ dipasangkan dengan gap, sehingga jika $S_{3}$ adalah nilai optimum dari penjajaran $A_{1}-B$ maka penjajaran $A$ - $B$ memiliki nilai

$$
S=S_{3}+d
$$

Dari tiga sub-masalah di atas, maka diperoleh nilai nilai optimum dari penjajaran $A-B$ adalah:

$$
\text { Soptimum }=\operatorname{Max}\left\{\begin{array}{c}
S_{1}+(\text { matauu }) \\
S_{2}+d \\
S_{3}+d
\end{array}\right.
$$

Langkah yang sama dilakukan untuk menentukan nilai $S_{1}, S_{2}$, dan $S_{3}$ pada tahapan berikutnya. Secara induktif, maka diperoleh persamaan:

$$
\begin{aligned}
& T(i, j) \\
& =\max \left\{\begin{array}{c}
T(i-1, j-1)+\operatorname{sim}(S 1(i), S 2(j)) \\
T(i-1, j)+d \\
T(i, j-1)+d
\end{array}\right.
\end{aligned}
$$

Dimana,
$T(i, j)=$ fungsi optimum pada penjajaran urutan DNA

$i=0,1,2, \ldots, \mathrm{m}$ (indeks kolom)

$j=0,1,2, \ldots, \mathrm{n}$ (indeks baris)

$\operatorname{sim}\left(S_{1}(i), S_{2}(j)\right)=\left\{\begin{array}{c}1, \text { match } \\ -1, \text { unmatch }\end{array}\right.$

$d=-2$

\subsection{Analisis fungsi pada relasirekursif $T(i, j)$}

Pada bagian sebelumnya telah dijabarkan langkah-langkah pada algoritma Needleman-Wunsch dalam mencari alignment paling optimal dari pembandingan dua urutan untuk melihat tingkat kemiripan urutan DNA tersebut. Diberikan relasi $T(i$, $j$ ) dalam pengisian nilai pada matriks yang dibentuk dan kemudian nantinya dijadikan acuan dalam menentukan alignment yang paling optimal. Pada bagian ini, akan dilakukan analisis terhadap relasi $T(i$ , j).

$$
T(i, j)=\max \left\{\begin{array}{c}
T(i-1, j-1)+\operatorname{sim}(S 1(i), S 2(j)) \\
T(i-1, j)+\text { gap penalty } \\
T(i, j-1)+\text { gap penalty }
\end{array}\right.
$$

Dapat dilihat bahwa i menunjukan urutan kolom di mana $\mathrm{i}=0,1,2, \ldots, \mathrm{m}$, dan $\mathrm{j}$ menunjukkan urutan baris pada tabel di mana $\mathrm{j}=0,1,2, \ldots, \mathrm{n}$. lebih jauh dapat dikatakan bahwa $\mathrm{i}$ dan $\mathrm{j} \in \mathbb{N}_{0}$ (himpunan bilangan cacah). Selanjutnya akan ditunjukkan bahwa nilai $T(i, j)$ adalah tunggal. Perhatikan bahwa nilai $T(i, j)$ adalah nilai maksimum, untuk menunjukkan nilai $T(i, j)$ adalah tunggal, maka haruslah ditunjukkan bahwa nilai maksimum adalah tunggal.

Andaikan $f(u)$ dan $f(v)$ untuk suatu $u, v \in \mathrm{S}$ merupakan nilai maksimum $f(x)$ untuk setiap $x \in \mathrm{S}$. Akan ditunjukkan $f(u)=f(v)$. Perhatikan bahwa $f$ (u) nilai maksimum $f(x)$, artinya $f(u) \geq f(x)$ untuk semua $x$ di S, akibatnya $f(u) \geq f(v)$. Selanjutnya perhatikan bahwa $f(v)$ nilai maksimum $f(x)$, artinya $f$ (v) $\geq f(x)$ untuk semua $x$ di S, akibatnya $f(v) \geq f(u)$.

Karena $u, v \in \mathrm{S}, \operatorname{dan} f(u) \geq f(v), f(v) \geq f(u)$, maka haruslah $f(u)=f(v)$. Artinya nilai maksimum suatu fungsi adalah tunggal, akibatnya nilai $T(i, j)$ tunggal. Berdasarkan Definisi 2.1.1, maka dapat dikatakan bahwa $T(i, j)$ adalah fungsi, di manaT: $\left(\mathbb{N}_{0} \times \mathbb{N}_{0}\right) \rightarrow$ $\mathbb{Z}$.

Selanjutnya jika dilihat lebih jauh berdasarkan Definisi 2.2.1., maka diketahui bahwa $T(i, j)$ merupakan fungsi rekursif dengan : 
a. Basis

$$
T(i, j)=0 \quad \text {, jika } i=j=0
$$

b. Rekurens

$$
\begin{aligned}
& T(i, j) \\
& =\max \left\{\begin{array}{c}
T(i-1, j-1)+\operatorname{sim}(S 1(i), S 2(j)) \\
T(i-1, j)+\text { gap penalty } \\
T(i, j-1)+\text { gap penalty }
\end{array}\right.
\end{aligned}
$$

untuk $i$ atau $j \geq 0$

\subsection{PenerapanAlgoritma Needleman-Wunsch pada DNA Rusa Timor dan RusaMerah}

Pada bagian akan dilakukan penerapan algoritma N-W untuk mengetahui kemiripan urutan DNA Rusa Timor dengan Rusa Merah. Berikut data urutan Rusa Timor dan Rusa Merah yang diperoleh dari BLAST (Basic Local Alignment Search Tool).

Tabel 4.1 Data urutan DNA Rusa Timor (Cervus timorensis) dan Rusa Merah (Cervus elaphus) yang

\begin{tabular}{|c|c|}
\hline $\begin{array}{c}\text { Nama } \\
\text { Species }\end{array}$ & Urutan DNA \\
\hline $\begin{array}{l}\text { Rusa Timor } \\
\text { (Cervus } \\
\text { timorensis) }\end{array}$ & $\begin{array}{l}\text { AGCAGGCATAGTAGGAACAG } \\
\text { CCTTAAGCCTACTGATTCGTG } \\
\text { CCGAACTGGGCCAACCTGGTA } \\
\text { CTCTGCTTGGAGACGACCAAA } \\
\text { TTTATAATGTTATCGTAACCGC } \\
\text { ACATGCATTCGTAATAATTTTC } \\
\text { TTTATAGTTATGCCAATTATAA } \\
\text { TTGGAGGATTTGGTAATTGAC } \\
\text { TAGTTCCCCTAATAATTGGTG } \\
\text { CCCCAGACATAGCATTCCCTC } \\
\text { GAATAAACAATATAAGCTTTT } \\
\text { GACTCCTCCCTCCTTCTTTCTT } \\
\text { ACTACTTTTAGCATCATCTATA } \\
\text { GTTGAAGCTGGCGCAGGAACA } \\
\text { GGCTGAACTGTATATCCCCCT } \\
\text { CTAGCTGGCAACTTAGCTCAC } \\
\text { GCAGGGGCTTCAGTAGACTTG } \\
\text { ACTATTTTTTCTTTACACTTGG } \\
\text { CAGGTGTTTCCTCAATTTTAGG } \\
\text { GGCCATTAACTTTATTACAAC } \\
\text { AATTATCAATATAAAACCCCC } \\
\text { TGCCATATCACAATATCAAAC } \\
\text { CCCACTATTTGTATGATCCGTA } \\
\text { TTAGTCACTGCTGTACTACTAC } \\
\text { TTCTCTCACTCCCTGTACTAGC } \\
\text { AGCCGGAATTACAATACTATT } \\
\text { AACAGACCGAAACTTAAATAC } \\
\text { AACCTTTTTTGACCCAGCAGG } \\
\text { AGGCGGAGATCCTA }\end{array}$ \\
\hline
\end{tabular}
diperoleh dari BLAST (Basic Local Alignment Search Tool)
Rusa Merah TGACAGACACACCATGAGAGC (Cervus CCTTGTGCTCCTCGCCCTGCCG elaphus) GCCCTGGCCACGCTCTGCCTC GCTGGTCGGGCAGATGCAAAG CCCGGTGATGCAGAGTCCGGC AAAGGCGCAGCCTTCGTGTCC AAGCAGGAGGGCAGCGAGGT GGTGAAGAGACTCAGGCGCTA CCTGGATCCTGGGCTGGGAGC CCCAGCCCCCTACCCAGATCC GCTGGAGCCCAAGAGGGAGG TGTGTGAACTCAACCCTGACT GTGACGAGCTAGCTGACCACA TCGGCTTCCAGGAGGCCTACC GGCGCTTCTACGGCCCGGTCT AGGGCTCGCAGCCCTGCCGAC CTGGCCGGCAGCCCCCAGCTC TGGCTTCTCTCCAGGACAATC ACTAGTGAATTCGCGGCCGCC TGCAGGTCGACCATATGGGAG AGCTCCCAACGCGTTGGATGC ATAGCTTGAGTATTCTATAGT GTCACCTAAATAGCTTGGCGT AATCATGGTCATAGCTGTTTC CTGTGTGAAATTGTTATCCGCT CACAATTCCACACAACATACG AGCCGGAAGCATAAAGTGTAA AGCCTGGGGTGCCTAATGAGT GAGCTAACTCACATTAATT

Sumber:http://www.ncbi.nlm.nih.gov/BLAST/

Dapat dilihat bahwa urutan DNA Rusa Timor (RT) memiliki panjang $(\mathrm{m})=611$, sedangkan untuk Rusa Merah (RM) memiliki panjang $(n)=607$. Selanjutnya dilakukan langkah-langkah dalam algoritma $\mathrm{N}-\mathrm{W}$ sehingga diperoleh urutan terbaik sebagai berikut: 


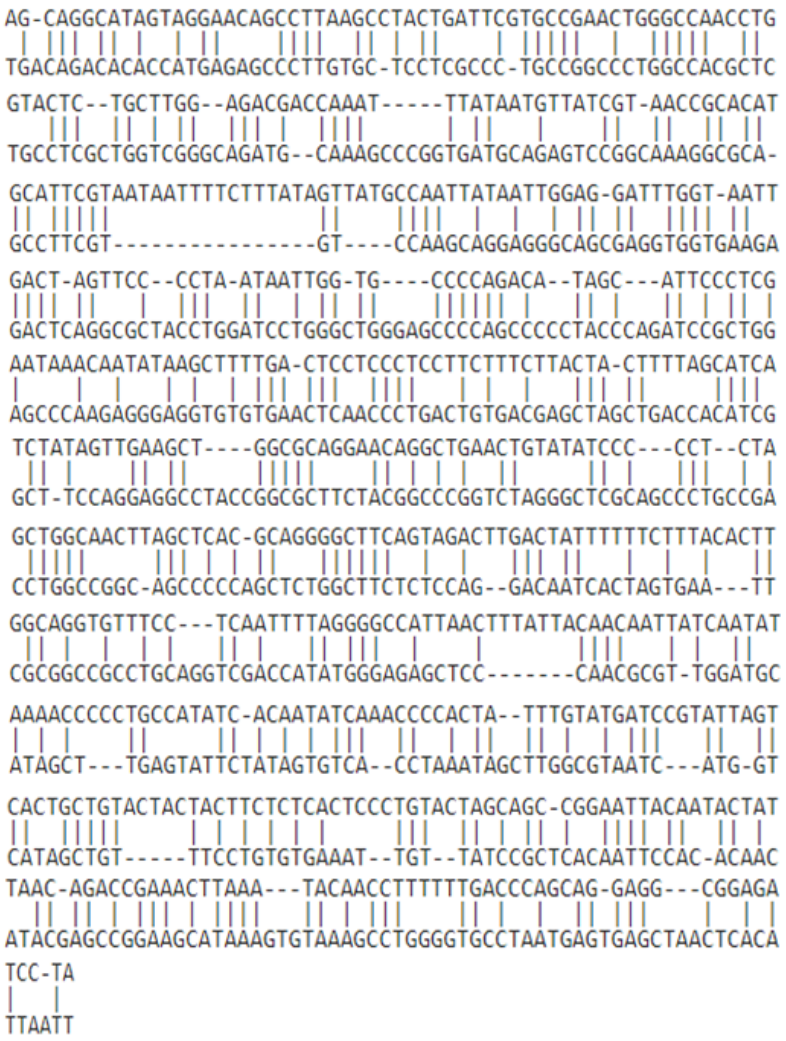

Dari alignment di atas dapat dilihat bahwa terbentuk 666 urutan pasangan basa dengan 322 match, 230 missmatch, dan 114 gap. Ini berarti kedua urutan DNA Rusa tersebut memiliki kemiripan sebesar $48 \%(322 / 666)$.

\section{Penutup}

Berdasarkan hasil dan pembahasan yang telah dilakukan dapat ditarik beberapa kesimpulan berikut yaitu:

a. Algoritma Needleman-Wunsch digunakan untuk menyelesaikan masalah penjajaran urutan dan mengetahui tingkat kemiripan urutan DNA makhluk hidup. Dalam algoritma ini digunakan program dinamik sebagai dasar penyelesaian masalahnya dengan menggunakan fungsi rekursif $T(i, j)$, di mana $T:\left(\mathbb{N}_{0} \times \mathbb{N}_{0}\right) \rightarrow \mathbb{Z}$.

b. Penerapan algoritma Needleman-Wunsch untuk membandingkan DNA, diperoleh alignment terbaik untuk urutan DNA Rusa Timor dan Rusa Merah, terbentuk 666 urutan pasangan basa dengan 322 match, dan 114 gap. Hal ini berarti kemiripan DNA Rusa Timor dan Rusa Merah sebesar $48 \%$.

\section{DAFTAR PUSTAKA}

Aminah, Aidawayati, R., Kreanajaya, A., 2013, Model Antrean Pesawat Terbang di Bandar Udara Internasional Hasanuddin Makassar, Jurnal Matematika,Statistika\&Komputasi Volume I : 11.

Bu'ulölö, I. C., Simamora, N., Tampubolon, S., Pinem, A., 2010, Sequence Alignment Menggunakan Algoritma Smith Waterman, Seminar Nasional Politeknik Batam, Sumatera Utara 2010 Volume 2 No. 2.

Khairunnisa, A., 2014, Matematika Dasar, Jakarta: PT Rajagrafindo Persada.

Kusuma, W. A., 2019, Sequence Alignment, Multiple Sequence Alignment, dan Pencarian Homologi, MIPANet School Series, Bogor, 11-13 Januari 2019.

Lokawati, H., 2016, Program Dinamis untuk Menyelesaikan Sequence Alignment, http://docplayer.info, diunduh jam 14.32 WITA, tanggal 24/10/2019.

Malendes, M. A., Bunyamin, H., 2017, Perbandingan Needleman-Wunsch dan Lempel-Ziv dalam Teknik Global Sequence Alignment: Keunggulan Faktorisasi Sempurna, Jurnal Teknik Informatika dan Sistem Informasi Volume 3 No. 1 : 57-68.

Munir, Rinaldi., 2010, Matematika Diskrit Revisi Keempat, Bandung: Informatika.

Ratnadewi, Prijono, A., Hendrianto, H., Pasaribu, N. T., Hasugian, M. J., 2016, Matematika Teknik untuk Perguruan Tinggi, Bandung: Rekayasa Sains.

Satra, R., Fuad, M., Hestriyandi, H., Iqbal, M., Iqbal, M., 2015, Analisis Performa Algoritma Needleman-Wunsch (NW) Urutanial pada Raspberry Pi, Seminar Nasional Riset Ilmu Komputer, Makassar, 3 April 2015.

Siagian, P., 1987, Penelitian Operasional : Teori dan Praktek, Jakarta : Universitas Indonesia Press.

Sukiman., 2006, Logika Himpunan, Yogyakarta: Hanggar Kreator.

Supranto, J., 1998, Pengantar Matriks, Jakarta: PT Rineka Cipta.

Torres, A., Cabada, A., Nieto, J.J., 2003, An Exact Formula for the Number of Alignments Between Two DNA Sequences, Taylor \& Francis Health Sciences Volume - : 1-4.

Wikipedia,

Asam deoksiribonukleat(https://id.wikipedia.org), diunduh jam 14.20 WITA, tanggal 28/03/2019.

Wikipedia, Bioinformatika(https://id.wikipedia.org), diunduh jam 14.32 WITA, tanggal 28/03/2019. 
Zen, M. R. F., Putri, S. W., Rasyid, M. F., 2006,

Penerapan Algoritma Needlman-Wunsch sebagai Salah Satu Implementasi Program Dinamis pada

Penjajaran DNA dan Protein,

http://informatika.stei.itb.ac.id , diunduh jam 15.00

WITA, tanggal 25/05/2019. 